\title{
STRA8 Gene
}

National Cancer Institute

\section{Source}

National Cancer Institute. STRA8 Gene. NCI Thesaurus. Code C104903.

This gene may be involved in spermatogenesis. 